Ilmenau University of Technology

Institute of Economics

Ilmenau Economics Discussion Papers, Vol. 27, No. 156

\title{
Is more diverse always the better? External knowledge source clusters and innovation performance in Germany
}

This is a preprint version of this article (AOM). All publishing rights are reserved for the Journal of Economics of Innovation and New Technology

Maryam Hajialibeigi

November 2021

Institute of Economics

Ehrenbergstraße 29

Ernst-Abbe-Zentrum

D-98693 Ilmenau

Phone 03677/69-4030

Fax 03677/69-4203

ISSN 0949-3859

https://www.tu-ilmenau.de/iedp 


\title{
Is more diverse always the better? External knowledge source clusters and innovation performance in Germany
}

\author{
Maryam Hajialibeigi*
}

\begin{abstract}
This study gives a new identity to a knowledge search mode named search diversity and investigates how it is more rigorous in capturing knowledge heterogeneity in comparison to general assessment of search breadth. By distinguishing between diversifying and expanding search domain as building blocks of broadening search scope, this study proposes a hybrid search strategy when it comes to analysis of the link between external search and innovation performance. While a positive trend is found for search breadth and innovation in this review, search diversity indicates a curvilinear pattern but with a steeper positivity than search breadth's. A prerequisite extension of this paper is to utilize a clustering method among different external sources acting as a reference to codify a diversity index for measuring the new search scheme. Also, the effect of usage of each cluster on innovation is empirically illustrated. This paper suggests that the optimal hybrid search outlook in respect to innovation is built up by initially increasing diversity in search up to the downturn point and then shifting into usage of same source clusters without helping diversity. This analysis provides practitioners with additional insights for managing external sourcing strategies and leveraging innovativeness.
\end{abstract}

Keywords: Search breadth, External search diversity, Search scope, Knowledge heterogeneity, Source clustering, Innovation performance

JEL classification: $O_{3}, C_{1}$

ORCiD: 0000-0002-6474-5752

\footnotetext{
* M. Sc.,Maryam Hajialibeigi, Department of Economic Sciences and Media, Ilmenau University of Technology, Ilmenau, Germany, m.h.a.beigi@gmail.com
}

\section{Introduction}


Creativity and innovation in today's world requires firms to have access to adequate knowledge (Hoffman et al. 1998; Romero and Martinez -Roman 2012) to develop potential competitive advantage. Open innovation theory which was formulated in Chesbrough's seminal paper (2003) as searching and utilizing external knowledge implies that abundant knowledge cannot be limited to firms' internal capacities (Gassmann and Enkel 2004; Dahlander and Gann 2010).

Although the border between firms and their external environment is not a sharp one when it comes to seeking for knowledge, by investing in R\&D activities (Dominici and Levanti 2011; Varga, Pontikakis, and Chorafakis 2014) and their employees' individual competencies (Galende and De la Fuente 2003), firms cannot access the supply of knowledge they might require to catch up with the fast-changing market circumstances. Firms have been involved with searching for knowledge outside their boundaries even before open innovation was theorized (Teece 1986; March 1991) but after Chesbrough's formulation it has been organized as a prominent practice when firms pursue innovation which they intend to commercialize (Gassmann and Endkel 2004; Dahlander and Gann 2010).

External search strategies have been investigated in literature from different points of view (Cohen and Levinthal 1990; Rosenkopf and Nerkar 2001). Search breadth provides opportunities to gain knowledge from different external sources enlarging enterprises' abilities in forming new ideas (Laursen and Salter 2006; Leiponen and Helfat 2010; Greco, Grimaldi, and Cricelli 2015; Gomez, Salazar, and Vargas 2016) and search depth gives the firms the opportunity to dig 'useful' sources of knowledge more carefully for cultivating new ideas (Katila and Ahuja 2002; Laursen and Salter 2006; Leiponen and Helfat 2011). The role search breadth and depth play on firms' performance in aggregation with internal $R \& D$ investments has been treated in the literature and it has been indicated that there is a positive relationship between search breadth and depth and innovation performance (Leiponen and Helfat 2010). There are also studies which have found curvilinear relationship between search strategies and innovation (Laursen and Salter 2006; Hwang and Lee 2010; Radicic 2020) due to leftover knowledge based on attention theory (Simon 1947; Ocasio 1997a, 2011b). There are studies which consider the moderating role of absorptive capacity (Escribano, Fosfuri, and Tribo 2009; Ferreras-Mendez et al. 2015) which refers to firms' ability in learning to exploit useful (for innovation process) external knowledge and integrate it with internal stock. Such learning attribute assists firms to avoid good amount of unneeded knowledge (Cohen 
and Levinthal 1990; Kim and Mauborgne 1998; Zahra and George 2002; Flor, Cooper, and OltraMestre 2018).

Although Search breadth has been perceived as the strategy for 'diverse' search for knowledge (Chiang and Hung 2010; Zhou and Li 2012), this study illustrates that a clear pattern to reveal the inherent heterogeneity dynamics in acquired knowledge by firms, cannot be fully grasped when assessing search breadth in its general sense. The question whether there is a latent dimension for openness which can give firms a direction to their intensifying search strategies is left untreated. Thus this article suggests a search dimension which is a supplement to search breadth or can be a component for it. As a prerequisite to the proposition of the new mode of knowledge exploration, a network structure for different external sources is provided according to a source clustering reference. A heterogeneity index is then corresponded to the source network to transform it into a measurable knowledge strategy which is called search diversity. A hybrid search strategy is developed which encapsulates magnitude and direction of an optimal policy by incorporating search diversity and search breadth. The further step this study takes is to examine the impact of this supplementary dimension of open innovation on technological innovation performance in complementarity to search breadth (hybrid). Although the main purpose of the clustering reference mentioned above is to use it for calculation of search diversity, the effect of utilization of each cluster on innovation performance is also evaluated.

The rest of the paper is organized as follows. In the next section external source clustering is shaped as a reference and the effects of different clusters on innovation performance are expanded followed by the development of the associated hypotheses. Next, external knowledge diversity is conceptualized based on the network structure of external sources and the impact of diversity index on innovation performance is theorized, then the hybrid strategy is discussed and the fundamental hypotheses are evolved. In the following section, underlying methods used in this study are introduced. Furthermore the results will be presented. Finally theoretical and managerial implications as well as conclusion of the whole study are discussed.

\section{Development of the theory and hypotheses}

\subsection{External source clustering}

The effect, utilization of most of individual external sources make on innovation, has been analyzed in previous studies and it has been shown that gaining information from those individual 
sources in aggregation with internal knowledge capacities generates overall positive effects on innovation but with different substances (Bruce et al. 1995; Gomez, Salazar, and Vargas 2016; Medase and Abdul-Basit 2020). This review intends to firstly inspect if there are any differences in the significance of the impact, different clusters of information sources (either market based or professional based) exert on innovation performance and to secondly use that clustering as a reference to calculate search diversity in the next section. Eleven external sources are included in the clustering routine. As an extension of the literature (Cassiman and Veugelers, 2002; Poot, Faems, and Vanhaverbeke 2009; Dong and Netten 2017) four groups of sources are aggregated in the reference according to the distance between them and their relative positions in firms business models: (1)vertical class: suppliers, private clients, public clients (2) horizontal class: competitors (3) societal class: consultants, government, private research institutes, professional associations (4) specialized class: universities, conferences, scientific journals. It is crucial to pay attention to the kind of information each class as a bundle might supply. By deepening knowledge extraction from vertical category, firms can get access to essential information clients provide in regard to customer needs and consumption patterns, also suppliers can supply substantial information about their own clients which could be firms' rivals, competition in the market and new logistic models. Thus vertical category can support information which significantly enhances firms' potential in idea productions to cover wider ranges of customer needs and contributes to commercialization process (Amara and Landry 2005). Knowledge gained from competitors as the primary source in the horizontal category contributes to the innovation process through supplying information about opponents' delicacies to consider as potential domains for firms to invest for idea production, also having knowledge about opponents' powers could give suggestions for technological and nontechnological extensions in the market (Dong and Netten 2017). Merger patterns in the corresponding market are also beneficial information gained from competitors for following strategies that gives firms more incentives to innovate not to lose competitive advantage. The other two categories do not include direct players in the market but digging them deep as partners in firms' business models can provide firms with critical information about market situation and market soon-to-be enabling them to be first movers in introducing new services and new business practices . Since they are not direct players in firms' corresponding markets, their impact might be less substantial on innovation than that of the vertical and horizontal classes. That logic contributes to the advancement of the three following hypotheses: 
H1a.Knowledge supplied by vertical and horizontal source categories positively influence innovation.

H1b.Knowledge supplied by societal and specialized source categories positively influence innovation.

H1c. The impacts of vertical and horizontal source clusters on innovation are more substantial than the effect of societal and specialized clusters.

\subsection{Diversity, breadth and hybrid strategy}

It has been indicated in the literature that utilization of higher number of external sources of knowledge (search breadth) is more likely to lead to higher innovation performance (Chiang and Hung 2010; J.Chen, Y.Chen, and Vanhaverbeke 2011; Terjesen and Petal 2015; Ferreras-Mendez et al. 2015). Accessing to more external sources contributes to pursuing broader and more general knowledge exploitation (Flor, Cooper, and Oltra-Mestre 2017) but that 'generality' does not necessarily give a vivid overview of knowledge heterogeneity. In some broadening search strategies, firms might encounter redundancies in the knowledge pool they have acquired from external sources and that in turn might leave them with inefficiencies in their search, given limited investment resources. It is crucial for firms to know which direction to choose in their intensifying search policy to improve their innovation process. Source clustering contributes to finding that direction since it draws borders to distinguish sources supplying similar information from the ones with non-similarities. It also gives a reference for finding a traceable pattern in heterogeneity dynamics of search strategies. As an example, by widening search breadth from 'conferences' to 'scientific journals' firms might not gain more differentiated knowledge despite the fact that search breadth has been increased from one to two. That is because knowledge supplied by conferences is very similar in nature to that of scientific journals. But widening search domain from 'conferences' to 'private clients' gives firms a better opportunity in gaining more differentiated knowledge while search breadth is identical. Therefore to optimize their search policies, firms require a direction in search which gives them a metric for optimal diversity in their knowledge exploration. In order to find such metric which exposes a trend between diversifying search and innovation performance, some steps need to be taken. The networking outlook on external sources and corresponding a diversity index to the whole network as a united entity, allows for a deeper 
look into dynamics of search where the direction can be better identified. Figure 1 below illustrates a generic source network.

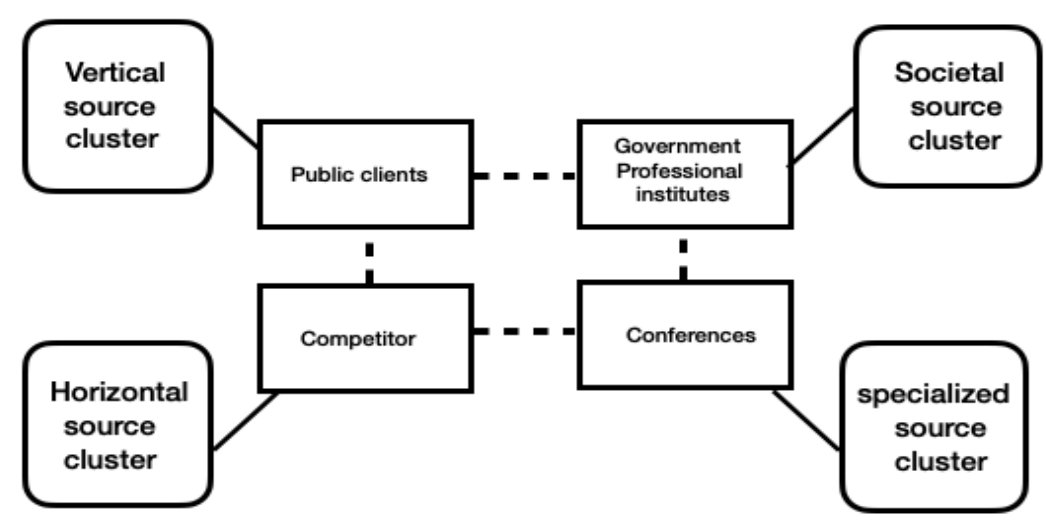

Figure 1. A Source network of five sources from four categories

Being inspired by the diversity index (Simpson index, Simpson, 1949) which is practiced in biology for quantifying natural species diversity and Herfindahl-Hirschman index (HHI score, Hirschman 1946; Herfindahl 1950) in economics for measuring the size of firms in relation to industries and a metric for the amount of competition among firms, this study introduces knowledge diversity index. If $N$ indicates the total number of external sources (search breadth) used by a firm and $n_{i}$ indicates the number of sources in each of the four categories (vertical, horizontal, societal and specialized) being used by that firm, then $P_{i}$ (for $\mathrm{i}=1 \ldots 4$ ) is defined as follows:

$$
P_{i}=\frac{n_{i}}{N}
$$

Then knowledge diversity index for the firm level is computed through the underneath equation:

$$
K D I_{1}=\frac{1}{\sum_{i=1}^{4} P_{i}^{2}}
$$

Since in some studies (Segarra- Cipres and Bou-LIusar 2018) including the current one, the evaluation of innovation performance is conducted in industry level this paper proposes a 
modification for determining knowledge diversity of external search in industries. If $N$ indicates total percentages of firms having used all eleven sources (search breadth) and if $u$ demonstrates the percentage of firms in a specific industry using a specific external source lying in one cluster (e.g. suppliers) then $U_{i}$ (e.g. summation of percentages of firms having used suppliers, private clients and public clients) is formulated as follows for each of the four source classes (for $i=1, \ldots$, 4):

$$
U_{i}=\sum u
$$

The knowledge diversity index in industry level is formulated as follows for (for $\mathrm{i}=1, \ldots, 4$ ):

$$
K D I_{2}=\frac{1}{\sum_{i=1}^{4}\left(\frac{U_{i}}{N}\right)^{2}}
$$

Figure 2 below summarizes how knowledge diversity is computed in an example by construction of the source networks and how it is distinguished from external search breadth as a complement for it.

\section{Knowledge search breadth in both cases $=5$}

$\underline{1}$

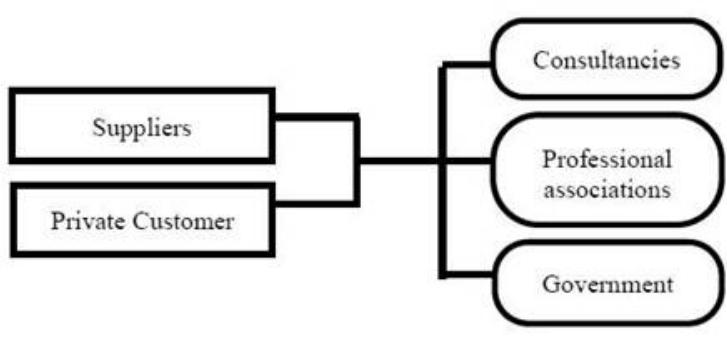

$n_{1}=2$ (number of sources in vertical class)

$n_{2}=3$ (number of sources in societal class)

$N=5$ (total number of sources or search breadth)

$P_{1}=\frac{n_{1}}{N}=\frac{2}{5} \quad P_{2}=\frac{n_{2}}{N}=\frac{3}{5}$

Diversity $=\frac{1}{\sum p_{i}^{2}}=\frac{1}{\left(\frac{2}{5}\right)^{2}+\left(\frac{3}{5}\right)^{2}}=1.9$ $\underline{2}$

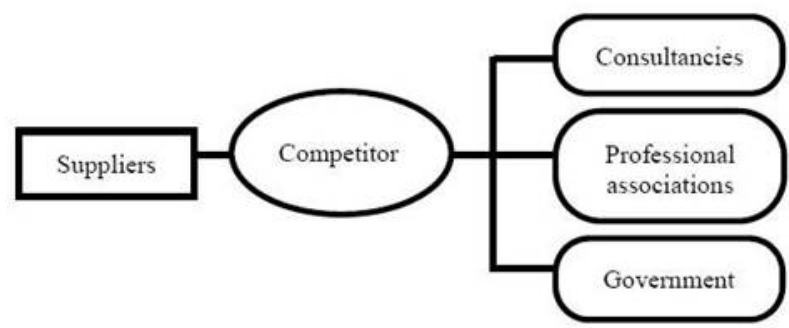

$n_{1}=1$ (number of sources in vertical class)

$n_{2}=1$ (number of sources in horizontal class)

$n_{3}=3$ (number of sources in societal class)

$N=5$ (total number of sources or search breadth)

$P_{1}=\frac{n_{1}}{N}=\frac{1}{5} \quad P_{\overline{2}}=\frac{n_{2}}{N}=\frac{1}{5} \quad P_{3}=\frac{n_{3}}{N}=\frac{3}{5}$

Diversity $=\frac{1}{\sum p_{i}^{2}}=\frac{1}{\left(\frac{1}{5}\right)^{2}+\left(\frac{1}{5}\right)^{2}+\left(\frac{3}{5}\right)^{2}}=\mathbf{2 . 2 7}$

Figurer 2. Verification of knowledge diversity

The two cases share the same search scope (search breadth) but the diversity of knowledge they acquire is different according to utilization of different source clusters. Furthermore the diversity index is capable of capturing the weight of acquired knowledge from each cluster in the whole network. In either of cases more than half of the sources belong to one cluster and that fact can be 
reflected in computation of diversity index (that is the reason why KDI in first case is less than 2 and less than 3 in second).

The networking structure of firms with external actors plays a substantial role in their performance (Grant 1996; Criscuolo et al. 2018). Knowledge search diversity promotes innovation mechanisms in two conducts. First, accessing to complementary knowledge improves idea production through refinements in the knowledge conversion and application mechanisms inside the enterprises. Second, heterogeneous knowledge obtained by firms provides them with highlighted information about development of different commercialization and implementation channels. When firms plan for their search strategy, by broadening knowledge exploration they gain general information which is valuable asset in their innovation process. Therefore, as covered and discussed fruitfully in the literature (Chiang and Hung 2010; Leiponen and Helfat 2010) search breadth exerts positive impact on innovation. On the other hand when it comes to information processing whose outcome is a vital enabler in innovation process, similarities existing in part of information, frustrates some of resources in the processing mechanism. If firms have a better sense of what type of knowledge better fills the gaps in their internal knowledge development and transfer mechanisms through reducing redundancy rates while amplifying knowledge domain, efficiency in processing procedure increases. The other side of the coin suggests that processing differentiated knowledge requires firms to possess adequate technological and non-technological assets such as trained employees and machinery and software. Conversion and application of much differentiated information might leave firms with lack of necessary assets thus diminishing the impact of search diversity on innovation. That is also justified according to attention-based theory of firms (Simon 1947; Ocasio 1997a, 2011b) which as Dong and Netten (2017) phrase suggests:' that firms as systems distribute attention. Attention refers to the ability of processing different sources of information and deriving necessary information for their functions (Garcia et al. 2000).' In that case firms might better off focusing more on similar sources of knowledge (search depth).

Accordingly this study, suggests a hybrid search strategy for questing external knowledge. Based on the arguments above, following a knowledge diversifying strategy accelerates innovation process in a more substantial way than following a general breadth strategy. But after a point on, restricted processing assets deteriorate the initial impact of diversity on innovation. The following hypotheses are evolved from the discussion and are analyzed empirically:

H2 a. External knowledge breadth is positively related with innovation performance 
H2 b. External search diversity establishes an inverted U-shaped relationship with innovation performance.

H2 c. Diversifying search scope in the beginning accelerates innovation more substantially than general broadening of knowledge exploration up to a downturn point.

\section{Data and measures}

\subsection{Data}

Metadata set is used based on the German innovation survey ${ }^{1}$ for evaluating the proposed hypotheses. The dataset has been used in other studies in the literature for the assessment of different factors influencing innovation behavior of firms and industries (Dong and Netten 2017; Radicic 2020). German innovation survey is a national survey of firm and industry level innovation encapsulating German industries information as part of the European Commission's community innovation surveys (CIS). CIS has its own contributions from industries from different countries throughout Europe. It is designed by the usage of methods developed by the Organization for Economic Cooperation and Development (OECD). Leibniz Center for European Economic Research (ZEW) has been active in gathering data regarding innovation dynamics of German industries since 1993; the survey includes annually provided statistics. It is directed on behalf of Federal Ministry of Education and Research (BMBF) and with participation of Institute of Applied Science (Infas) and Institute for Systems and Innovation Research (Fraunhofer ISI). It contains information about a range of industries including manufacturing, service and retailing from beverage industries to textiles and information service activities. A two yearly based modification happens to the dataset for omitting firms which are not active anymore or do not function as individual bodies due to mergers or acquisitions in the market; also new entrants with their innovation activities are added. The German innovation survey is designed as a panel survey and its size might face changes throughout years. It provides information about introduction of new products, services and processes as well as expenditures for innovation, market advancements with new products, new services and improved processes. For the purpose of this study CIS16 is utilized which contains innovation behavior of German industries through the time span of 2014-2016.

\footnotetext{
${ }^{1}$ https://www.zew.de/en/publications/zew-expertises-research-reports/research-reports/innovations/mannheim-innovation-panel-the-annual-germaninnovation-survey
} 
The set includes data for utilization of the eleven external sources and the rate of introduction of new or significantly improved processes and products for firms in the time span of two years. The reference set makes up to 85 industries comprise of 143,608 large and SME firms in three sectors of manufacturing, service and retail.

\subsection{Variables and Measures}

\subsubsection{External knowledge source clusters}

Since this study performs the empirical analysis in industry level, the measurement weights for the four clusters of external sources follows as the summation of the percentages of firms having used sources in each cluster divided by the percentages of firms not having used those sources in the same category from 2014 to 2016. If $u_{j}$ denotes the percentage of firms having used source (j) in each cluster and $n u_{j}$ denotes the percentage of firms not having used source $(j)$ in the same cluster , then the weight of each cluster is calculated in the following way (for $i=1, \ldots, 4$ ):

$$
x_{i}=\sum \frac{n_{j}}{n u_{j}}
$$

For vertical category $(j)=1,2,3$; for horizontal category $(j)=1$; for specialized category $(j)=1,2,3$ and for societal category $(j)=1,2,3,4$.For example for vertical category percentage of firms having used suppliers, private clients and public clients are added up and divided by the addition of percentages of firms who have not used suppliers, private clients and public clients in each industry. This calculation is the modification of average scores for depth (following Larsen \& Salter 2006) for industries. Based on such calculations vertical class, horizontal class, societal class and specialized class will be treated as independent variables in the hypothesis testing.

\subsubsection{External search breadth}

Since the knowledge search scope in industries is targeted in this study, search breadth for different industries is estimated as the summation of percentages of firms in each industry which have utilized different external knowledge sources (eleven sources included). If $u_{i}$ demonstrates the percentage of firms having used source $i$, then width of search breadth for industries is evaluated as: 


$$
\text { Breadth }=\sum_{i=1}^{11} u_{i}
$$

That estimation as knowledge search breadth is treated as one of independent variables in analytical models.

\subsubsection{External knowledge diversity}

Since this study analyzes the role of external knowledge diversity on innovation in industries, the modified version of the diversity index expressed in equation (5) in section 2.2 is utilized. Using that formula knowledge diversity index for each industry is calculated for source network of each industry rather than each firm. Percentages of usage of different sources are considered to compute diversity index which serves as the independent variable in hypothesis testing.

\subsubsection{Innovation performance}

In this study process and/or product innovation performance is addressed as the dependent variable and the role of knowledge diversity, knowledge breadth and individual source clusters in innovation performance is assessed through hypothesis testing models. The aggregate average of new or significantly improved products or services introduced by manufacturing or service based firms in each industry in the time span of two years (2014-2016) is considered as product innovation. Meaning, the percentage of newly introduced or significantly improved products in respect to total number of firms in each industry is the proxy for product innovation performance of each industry. The same applies to process innovation performance. The average of both together is provided in CIS16 and is treated as a proxy for product/process innovation performance of industries and is considered as the dependent variable in the evaluating models.

\subsection{Control variables}

\subsubsection{Sector dummy}

A dummy variable is considered in the model to control for the sector differences of the industries. If the highest percentage of firms in each industry belongs to service sector $\mathbf{0}$ is corresponded as the industry type dummy. If the highest percentage of firms belong to manufacturing $\mathbf{1}$ is corresponded, otherwise $\mathbf{2}$ is assigned for retailing sector. 


\subsubsection{Market size}

It is important to see what the market spectrum each industry is active in. Percentage of firms active in local market, percentage of firms active in national market, percentage of firms active in European market and percentage of firms active in international market are considered as factors determining the market size. The score average of these percentages with weights $1,4,8$ and 16 respectively defines the market size for the hypothesis testing. Those weights are used in order to differentiate the relative domain of different geographical spectrums.

\subsection{3. $R \& D$ expenditure}

The intensity of internal R\&D is considered as a control variable which demonstrates the industry's reliance on internal resources for innovation. In houses $R \& D$ expenditure the industry invests for product and process innovation is the proxy for R\&D intensity which is controlled in hypothesis testing.

Table 1 demonstrates description and scale of variables being used for the sake of analysis. Table 2 , Table 3 and Table 4 summarize the descriptive statistics of variables analyzed in regression models related to sections 2.1 and 2.2 respectively. 


\section{Table 1}

Summary of measures

\begin{tabular}{|c|c|c|}
\hline Variable & Description & Scale \\
\hline Vertical cluster & $\begin{array}{l}\text { Summation of percentage of firms having used suppliers, private clients, } \\
\text { public clients divided by summation of percentage of firms not having used } \\
\text { suppliers, private clients or public clients }\end{array}$ & $0-4$ \\
\hline Horizontal cluster & $\begin{array}{l}\text { percentage of firms having used competitors divided by percentage of firms } \\
\text { not having used competitors }\end{array}$ & $0-5$ \\
\hline Societal cluster & $\begin{array}{l}\text { summation of percentage of firms having used consultants, government, } \\
\text { private research institutes and professional associations divided by } \\
\text { summation of percentage of firms nothing used consultants, government, } \\
\text { private research institutes and professional associations }\end{array}$ & $0-7$ \\
\hline Specialized cluster & $\begin{array}{l}\text { Summation of percentage of firms having used universities, conferences and } \\
\text { scientific journals divided by summation of percentage of firms not having } \\
\text { used universities, conferences and scientific journals. }\end{array}$ & $0-6$ \\
\hline Diversity & $\begin{array}{l}\text { Inverse of the summation of fraction of clusters divided by total sources } \\
\text { squared } \frac{1}{\sum_{i=1}^{4}\left(\frac{U_{i}}{N}\right)^{2}}\end{array}$ & $0-2$ \\
\hline Breadth & $\begin{array}{l}\text { Summation of percentages of usage of all eleven sources in each industry, } \\
\sum_{i=1}^{11} u_{i}\end{array}$ & $0-3$ \\
\hline $\mathrm{R} \& \mathrm{D}$ & In house $\mathrm{R} \& \mathrm{D}$ expenditure & $27-110$ \\
\hline Industry dummy & Whether industries belong to manufacturing, service or retail & $\begin{aligned} 2=\text { retail }, 1 & =\text { manufacturing } \\
0 & =\text { service }\end{aligned}$ \\
\hline Market size & $\begin{array}{l}\text { weighted average of percentage of firms in the industry who sell in local, } \\
\text { national, European and international markets with } 1,4,8,16 \text { as weights } \\
\text { respectively }\end{array}$ & $0-30$ \\
\hline
\end{tabular}

Table 2

Descriptive statistics and correlations-part 1

\begin{tabular}{|c|c|c|c|c|c|c|c|c|}
\hline & Mean & SD & (1) & (2) & (3) & (4) & (5) & (6) \\
\hline Vertical & 0.74 & 0.46 & & & & & & \\
\hline Horizontal & 1.68 & 0.85 & 0.81 & & & & & \\
\hline Societal & 1.65 & 1.17 & 0.80 & 0.74 & & & & \\
\hline Specialized & 2.22 & 1.07 & 0.65 & 0.56 & 0.72 & & & \\
\hline $\mathrm{R} \& \mathrm{D}$ & 5.83 & 2.28 & -0.18 & -0.1 & -0.11 & -0.16 & & \\
\hline $\begin{array}{l}\text { Industry } \\
\text { dummy }\end{array}$ & 0.5 & 0.6 & 0.16 & -0.7 & -0.23 & -0.72 & 0.60 & \\
\hline Market size & 11.81 & 6.36 & -0.01 & 0.09 & 0.14 & -0.02 & -0.1 & -0.39 \\
\hline
\end{tabular}


Table 3

Descriptive statistics and correlations-Part 2

\begin{tabular}{cccccc}
\hline & Mean & SD & $(1)$ & $(2)$ & $(3)$ \\
\hline Diversity & 0.13 & 0.6 & & & \\
RD & 5.83 & 2.28 & 0.11 & & \\
Industry dummy & 0.5 & 0.6 & -0.09 & -0.02 & \\
Market Size & 11.81 & 6.36 & 0.13 & 0.38 & 0.45 \\
\hline
\end{tabular}

Table 4

Descriptive statistics and correlations-part 3

\begin{tabular}{cccccc}
\hline & Mean & SD & $(1)$ & $(2)$ & $(3)$ \\
\hline Breadth & 1.09 & 0.35 & & & \\
RD & 5.83 & 2.28 & 0.4 & & \\
Industry dummy & 0.5 & 0.6 & -0.05 & -0.05 & \\
Market Size & 11.81 & 6.36 & 0.26 & 0.46 & 0.45 \\
\hline
\end{tabular}

\section{Methodology and results}

Most of the variables follow a normal distribution pattern so a linear model is chosen to fit to the data. Furthermore linear model can mostly result in robust outcomes when the residuals meet the normality assumption. I directed a quantile-quantile plot for approval of the normality distribution of the residuals (Bai and $\mathrm{Ng} 2005$. To choose between fixed effects and random effects I conducted block-wise Granger causality test (exogeneity) and since the difference between the effects were not substantial I decided for random effects.

\subsection{External sources and innovation}

Ordinary least square (OLS) and generalized least square model (GLS) are performed for testing the validity of $\mathrm{Hla}, \mathrm{Hlb}$ and $\mathrm{H} 1 \mathrm{c}$. Table 5 presents the results for ordinary least squares and generalized least squares regressions. The analytical model is constructed as the following: 


$$
\begin{gathered}
Y=\beta_{0}+\sum_{i=}^{4} \beta_{i} x_{i}+\beta_{5} R \& D \text { intensity }+\beta_{6} \text { marketsize } \\
+\beta_{7} \text { industry dummy }
\end{gathered}
$$

Where $Y$ estimates product/process innovation performance and $x_{i}$ demonstrate aggregation value of source clusters for $i=1 \ldots 4$. R\&D intensity reveals a positive association with innovation which is statistically significant and consistent with literature (Love and Mansury 2007; Ebersberger and Herstad 2013). The industry distinction variable negatively associates with the innovation, which can be interpreted due to higher rates of new or significantly improved offerings in service sector in comparison to manufacturing and retail. Market size has statistically significant and positive effect on innovation, which is based on the reason that the industries who serve bigger markets are more likely to afford accessing to essential resources for their innovation activities and have more capacities to commercialize their innovation outcomes rather than the ones active in smaller markets like local territories. Vertical category of knowledge sources including suppliers, private clients and public clients as well as the horizontal class containing competitors impact the innovation in a positive way. That follows, concentrating to gain more information from such sources for external knowledge leads to higher rates of innovation for firms and industries. Societal and specialized classes are also statistically significant and positively related to innovation. Deepening search for knowledge from those clusters also accelerates innovation activities and outcomes. The latter induction supports $\mathrm{H} 1 \mathrm{a}$ as well as $\mathrm{H} 1 \mathrm{~b}$. The results indicate that focusing on searching more intensely for knowledge from vertical and horizontal sources increases innovation performance more substantially than the other two classes (see section 2.1), Thus H1 c is fulfilled. 
Table 5

Random effect OLS and GLS for source clusters and innovation

\begin{tabular}{ccc}
\hline & OLS & GLS \\
\hline Vertical cluster & $9.50^{* * * *}$ & $10.42^{* * *}$ \\
& $(3.062)$ & $(2.967)$ \\
Horizontal cluster & $7.31^{* * *}$ & $7.01^{* * *}$ \\
& $(2.38)$ & $(2.329)$ \\
Societal cluster & $4.19^{* * *}$ & $3.88^{* * *}$ \\
& $(1.352)$ & $(1.367)$ \\
Special cluster & $3.47^{* *}$ & $3.15^{* * *}$ \\
& $(1.815)$ & $(1.741)$ \\
R\&D & $3.19^{* * *}$ & $2.79^{* * * *}$ \\
& $(0.69)$ & $(0.729)$ \\
Industry dummy & $-7.16^{* * *}$ & -6.13 \\
& $(2.651)$ & $(2.806)$ \\
Market size & $1.19^{* * *}$ & $1.22^{* * *}$ \\
& $(0.299)$ & $(0.282)$ \\
Intercept & $-6.72^{*}$ & -4.49 \\
& $(10.056)$ & $(10.154)$ \\
$R^{2}$ & 0.56 & 0.57 \\
Adjusted $R^{2}$ & 0.52 & 0.53 \\
\hline
\end{tabular}

Note: ${ }^{*} \mathrm{p}<0.1 ;{ }^{* *} \mathrm{p}<0.05 ;{ }^{* *} \mathrm{p}<0.01$ - standard errors are in parenthesis. Dependent variable is innovation performance

\subsection{External knowledge strategies and innovation}

OLS and GLS are directed for evaluating H2s. A further assessment of $\mathrm{H} 2 \mathrm{~b}$ is also performed with quantile regression to investigate the curvilinear relationship between search diversity and innovation and to estimate the turning point in the pattern. The analytical models for testing hypotheses' validity are formed in the following:

$Y=\beta_{0}+\beta_{1}$ breadth $+\beta_{2} R \& D$ intensity $+B_{3}$ marketsize $+B_{4}$ industry dummy

$$
\begin{gathered}
Y=\beta_{0}+\beta_{1} \text { diversity }+\beta_{2} \text { diversity }{ }^{2}+\beta_{3} R \& D \text { intensity }+B_{4} \text { marketsize } \\
+B_{5} \text { industry dummy }
\end{gathered}
$$

Where $Y$ estimates technological innovation performance. OLS and GLS results presented in Table 6 , confirm a linearly positive relationship between search breadth and technological innovation performance. The outcome holds no deviation from evaluations in the literature and leads to fulfillment of $\mathrm{H} 2 \mathrm{a}$. As for testing $\mathrm{H} 2 \mathrm{~b}$ quantile regression is performed in addition to OLS and GLS models. Table 7 compares the results and demonstrates consistency between findings of the three models. Unlike the regular linear regression which uses the least squares to calculate the 
conditional mean of the response, quantile regression estimates the conditional median of the response and that can lead to a better assessment of the turning point in the trend between search diversity and innovation. In this analysis, statistically significant results are obtained for the quantile regression at $\mathrm{p}=0.6$, implying that diversifying search positively and statically significantly associates with innovation up to a turning point at $60^{\text {th }}$ percentile which is appraised through bootstrapping and kernel methods. Also the outcomes suggest that the diminishing effect of diversity on innovation occurs more slowly than the reinforcing positive one. Thus $\mathrm{H} 2 \mathrm{~b}$ is validated. Comparing the positive impact of search breadth with that of search diversity on innovation (see Table 6 and Table 7) leads to validity proof of H2 c. R\&D intensity, industry distinction variable and market size behave in the same way as in the models supporting H1s. Figure 3 below illustrates propositions and discussions of this study in a concise and encompassing way.

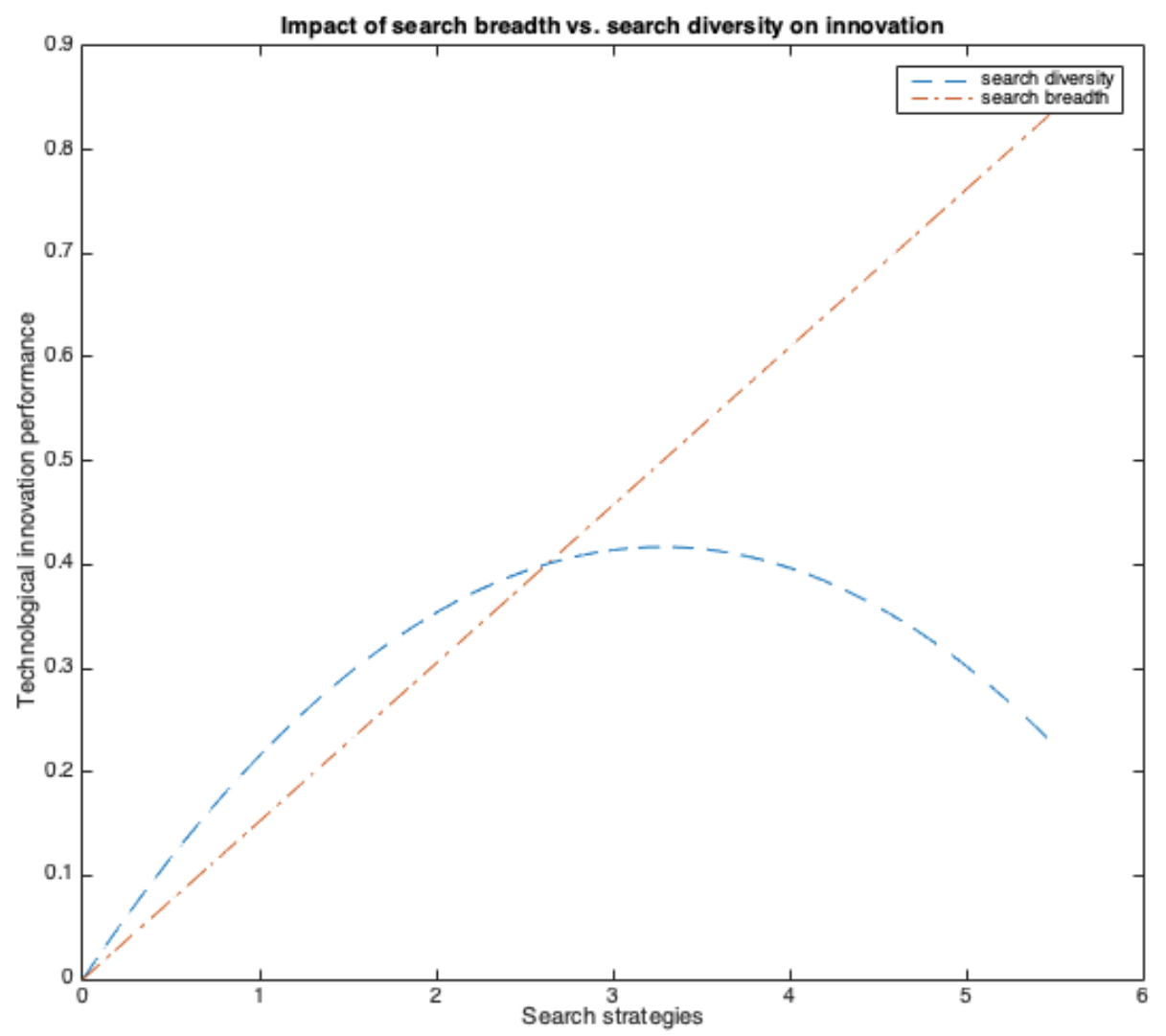

Figure 3. Search breadth, search diversity and a hybrid search strategy 
Diversifying search scope (hyperlinked pattern) accelerates innovation performance in a more substantial way than general broadening search span (dotted pattern). That is empirically demonstrated through validity proof of $\mathrm{H} 2$ c. Therefore increasing diversity in search for knowledge is initially a better improvement for innovation performance. Since the slope of search breadth is lower than the one related to positive impact of search diversity in the initial stage and due to existence of a downturn point in diversity-innovation pattern (see section 2.2 and 4.2), the two strategies collide at a point. Note that the point is not necessarily where the impact of diversity on innovation begins to drop .Such point is critical in decision making in pursuing knowledge search strategies. That is where firms need to decide to make a shift in their diversifying search extent into general broadening knowledge exploration. Put it differently, at the collision point firms (industries) are better off in their innovation process if they start to add to the number of external sources they explore from same clusters or deepening their search from same sources without letting diversity increase. That can be achieved by not exploiting more sources from more source clusters (see section 2.2 , Figure 2) and by scaling external knowledge diversity using diversity indexes introduced in section 2.2 (equations (2) and (4)).

\section{Table 6}

Random effects OLS and GLS for breadth and innovation

\begin{tabular}{|c|c|c|}
\hline & OLS & GLS \\
\hline Breadth & $\begin{array}{c}0.15 * * * \\
(0.04)\end{array}$ & $\begin{array}{c}0.15 * * * \\
(0.05)\end{array}$ \\
\hline $\mathrm{R} \& \mathrm{D}$ & $\begin{array}{c}0.03 * * * \\
(0.007)\end{array}$ & $\begin{array}{c}0.03 * * * \\
(0.007)\end{array}$ \\
\hline Industry Dummy & $\begin{array}{c}-0.05 * * \\
(0.03)\end{array}$ & $\begin{array}{c}-0.05 * * * \\
(0.02)\end{array}$ \\
\hline Market size & $\begin{array}{c}0.007 * * * \\
(0.002)\end{array}$ & $\begin{array}{c}0.008 * * * \\
(0.003)\end{array}$ \\
\hline Intercept & $\begin{array}{c}0.16 * * * \\
(0.05)\end{array}$ & $\begin{array}{c}0.17 * * * \\
(0.04)\end{array}$ \\
\hline$R^{2}$ & 0.546 & 0.553 \\
\hline Adjusted $\boldsymbol{R}^{2}$ & 0.524 & 0.531 \\
\hline
\end{tabular}

Note: ${ }^{*} \mathrm{p}<0.1 ; *^{*} \mathrm{p}<0.05 ; * * * \mathrm{p}<0.01-$ standard errors are in parenthesis. Dependent variable is innovation performance 
Table 7

Random effects OLS, GLS and quantile regression for diversity and innovation, Turning point $(p)=0.6$

\begin{tabular}{|c|c|c|c|c|}
\hline & OLS & GLS & quantile kernel & quantile bootstrap \\
\hline Diversity & $\begin{array}{c}0.25^{* *} \\
(0.1)\end{array}$ & $\begin{array}{c}0.23 * * \\
(0.097)\end{array}$ & $\begin{array}{c}0.22^{*} \\
(0.128)\end{array}$ & $\begin{array}{l}0.23^{* *} \\
(0.095)\end{array}$ \\
\hline Diversity squared & $\begin{array}{c}-0.04^{* *} \\
(0.018)\end{array}$ & $\begin{array}{l}-0.03 * * \\
(0.018)\end{array}$ & $\begin{array}{c}-0.03 \\
(0.024)\end{array}$ & $\begin{array}{l}-0.03 * * \\
(0.017)\end{array}$ \\
\hline $\mathrm{R} \& \mathrm{D}$ & $\begin{array}{c}0.03 * * * \\
(0.007)\end{array}$ & $\begin{array}{c}0.03 * * * \\
(0.007)\end{array}$ & $\begin{array}{c}0.03 * * * \\
(0.008)\end{array}$ & $\begin{array}{c}0.03 * * * \\
(0.006)\end{array}$ \\
\hline Industry dummy & $\begin{array}{c}-0.06^{* *} \\
(0.027)\end{array}$ & $\begin{array}{l}-0.05^{* *} \\
(0.028)\end{array}$ & $\begin{array}{c}-0.09 * * * \\
(0.032)\end{array}$ & $\begin{array}{c}-0.09 * * * \\
(0.026)\end{array}$ \\
\hline Market size & $\begin{array}{c}0.01 * * * \\
(0.002)\end{array}$ & $\begin{array}{c}0.01 * * * \\
(0.003)\end{array}$ & $\begin{array}{c}0.009 * * * \\
(0.003)\end{array}$ & $\begin{array}{c}0.009 * * * \\
(0.002)\end{array}$ \\
\hline Intercept & $\begin{array}{c}0.28 * * * \\
(0.036)\end{array}$ & $\begin{array}{c}0.29 * * * \\
(0.042)\end{array}$ & $\begin{array}{c}0.349 * * * \\
(0.046)\end{array}$ & $\begin{array}{c}0.349 * * * \\
(0.033)\end{array}$ \\
\hline$R^{2}$ & 0.52 & 0.51 & 0.61 & 0.63 \\
\hline Adjusted $R^{2}$ & 0.49 & 0.48 & 0.60 & 0.61 \\
\hline
\end{tabular}

Note: ${ }^{*} \mathrm{p}<0.1 ;{ }^{* *} \mathrm{p}<0.05 ;{ }^{* * *} \mathrm{p}<0.01-$ standard errors are in parenthesis. Dependent variable is innovation performance

\subsection{Robustness check}

In this study, random effects are used and that is a reason for not having a high probability of reverse causality. Since still the probability would have existed that some omitted variable(s) be impactful on diversity, breadth and source clusters as explaining factors and innovation performance as the response at the same time, some robustness checks are conducted. A firm's behavior of using external knowledge sources might be influenced by the industry pattern (Dong and Netten 2017) therefore conducting models with industry measurements can be a modifying approach for overcoming endogeneity (which is the approach in this review).Secondly, Conditions for existence of possible collinearities in need of treatment among variables in Table 2 (source clusters) are not fulfilled according to results of collinearity test and calculation of VIF and condition indices, thus the regression findings are not affected by correlations between the regressors. Furthermore because percentage of firms with innovative products and services is considered as the proxy to industries' innovation performance, quantile regression with two different approaches is performed for the diversity-innovation relationship and consistent results are obtained. As a final check I followed Lind and Mehlum (2010) and Dong and Netten (2017) to justify for a non-linear relationship in testing $\mathrm{H} 2 \mathrm{~b}$, which concludes existence of a U-shaped relationship if the slope of the U-shape is increasing at low values and decreasing at high values of the data set. The findings of the test are consistent with the regression results. Finally robust OLS regressions were performed for evaluating all the proposed hypotheses throughout the whole 
study and no significant deviation from the presented models were found. Those verifications provide evidence for robustness in findings.

\section{Discussion and conclusion}

\subsection{Theoretical and practical inferences}

This study takes a deeper look into the external knowledge strategies of firms and industries by introducing a dynamic dimension of knowledge search domain. The introduced dimension provides an analytical metric for diversity in search for external knowledge. The whole spectrum

of search for external knowledge has always been applied in previous studies in terms of search breadth. In that sense search breadth (by its original definition) embodied range and diversity of search scope without having an overview on how these two entities interact .This article finds a method to reflect the diversity aspect of search strategies in a conceivable and traceable way. In other words external search diversity gives an identity and a metric of measurement for dynamics of diverse search inherent in search breadth. This review creates a border between expanding search range and diversifying knowledge hunt. In that sense and as indicated, search diversity serves as a 'direction' aspect to search scope for realizing more optimal search policies. It is suggested and empirically demonstrated that diversifying information exploration as a measurable strategy improves the knowledge architecture of firms and therefore contributes to the impact of information processing outcomes on technological innovation. This review also theorizes the impact of different external source clusters on innovation performance and justifies their different impacts empirically. Following Medase and Abdul-Basit (2020) (concluded for individual sources), it is indicated that clusters of sources which include direct market players, impact technological innovation performance of firms (industries) in a more substantial way. The primary objective behind the clustering routine is to utilize it as a reference in formulating an index for search diversity. Considering the network of external sources, highlights a more comprehensive way of optimizing knowledge exploration channels for firms and industries. By reflecting more dynamics of external search, firms are provided with a deeper overview on how to construct their network of relationships with external partners and how to adjust their positions in their own business models. Therefore not only improvements in cooperation structures can be considered by firms but also opportunities for business model innovations can be exploited. It is to the best 
interest of firms to know how their external knowledge strategies assimilated with their internal capacities would provide them with more creativity potentials. Therefore by getting hands on deeper dynamics of search for external knowledge, firms are better off in enhancing their organizational attributes. Absorptive capacity as the organizations ability for capturing valuable knowledge from the outside world is an organizational trait influenced and improved by knowledge assimilated inside the corporation. Thus, optimizing knowledge strategies affects that important determining factor of innovation in a significant way in addition to its all other impacts. This study formulates dynamics of diverse search in two different levels; firm and industry level. Search breadth as the basic knowledge strategy is utilized for that formulation. We found different patterns between external search breadth and innovation and that of search diversity as breadth's complement component. While search breadth follows a positive trend with innovation, search diversity impacts innovation in a curvilinear manner. Since complementarity in the acquired information from external sources advances knowledge infrastructure and architecture, diversifying knowledge quest accelerates innovation performance in a more substantial manner than general search broadening. It can be considered that the curvilinear pattern found for the link between search breadth and innovation in many studies (Laursen and Salter 2006; Hwang and Lee 2010) have been due to integrated footsteps of diversity trend inside search breadth which is extracted in this study, and its impact on innovation is examined individually and jointly with search breadth. That trend on the other hand diminishes at some point while search breadth still enhances innovation performance from that point on (see section 4.2, figure 3). The proposed hybrid strategy suggests that based on their technological and non-technological resources firms are better off in improvement of innovation performance by diversifying search scope and look for knowledge from different source clusters but after the collision point of diversity with breadth (see section 4.2 figure 3 ) they are recommended to broaden their search scope without letting diversity increase through limiting their search to less rather than more search clusters.

In summery knowledge diversity is a key concept directing firms' (industries') external search strategies into a more influential character for innovation and it is advantageous for firms to take into account what the extent of their acquired knowledge heterogeneity needs to be in respect to different innovation goals. 


\subsection{Limitations and future research}

First of all in this study the roles of external source clusters and diversity on finalized product and process innovation are considered and not on any steps taken throughout the formation of those innovations. Also unimplemented innovation and innovative activities which have been abandoned by firms during the time span of this study have not been considered in the innovation performance of firms and industries. It gives a new avenue of empirical research to consider abandoned innovation activities in addition to the finalized innovations introduced to the market as part of innovation performance. Secondly the dataset used in this study contains information related to the time frame of 2014-2016.It would be an interesting research opportunity to investigate insights related to other (different) time spans. Finally, I have used a panel data derived from industries in German economy thus the results are applicable to that economy and other European industrial countries (such as Denmark, Netherlands, Sweden, etc.,) with similar socioeconomic features. It is likely to interpret same conclusions for industrial and industrializing countries elsewhere (such as United States, Canada, Brazil, etc.,) but it is difficult to generalize the results for developing countries (using same dataset) due to their strongly different market attributes. Therefore, research about other economies may serve to corroborate the general character of the insights.

\section{Acknowledgement}

Special thanks go to Professor Dr.Oliver Budzinski for his consistent support and precious contributing comments which contributed to the quality of final research and empowered the decision for publication. Also Mr. Eng. Mahdi Mousavi is appreciated for editing improvements.

This research did not receive any specific grant from funding agencies in the public, commercial or not-for-profit sectors.

\section{'Declaration of Interest: none'}




\section{References}

Abdul Basit, S., and K. Medase. 2019. "The diversity of knowledge sources and its impact on firm-level innovation." European Journal of Innovation Management, 22(4): 681-714.

Amara, N., and R. Landry. 2005. "Sources of information as determinants of novelty of innovation in manufacturing firms: Evidence from the 1999 statistics Canada innovation survey." Technovation, 25(3): 245-259.

Bai, J., and S. Ng. 2005. "Tests for skewness, kurtosis, and normality for time series data." Journal of Business \&Economic Statistics, 23(1): 49-60.

Barney, J.B. 1986. "Strategic factor markets: Expectations, luck and business strategy." Management Science, 21(1986): 1231-1241.

Bathelt, H., and N. Schuldt. 2008. "Between luminaires and meat grinders: International trade fairs as temporary clusters." Regional Studies, 42(6): 853-868.

Becheikh, N., R. Landry, and N. Amara. 2006. "Strategic determinants of technological innovation in manufacturing SMEs." Canadian Journal of Administrative Sciences/Revue Canadienne Des Sciences de L Administration, 23(4): 275-300.

Berchicci, L. 2013. "Towards an open R\&D system: Internal R\&D investment, external knowledge acquisition and innovative performance." Research Policy, 42(1): 117-127.

Brockhoff, K. 1992. "R\&D cooperation between firms — A perceived transaction cost perspective." Management Science, 38(4): 514-524.

Bruce, M., F. Leverick, D. Littler, and D. Wilson. 1995. "Success factors for collaborative product development: A study of suppliers of information and communication technology." R\&D Management, 25(1): 33-44.

Burt, R. S. 1992. "Structural holes: The social structure of competition." Cambridge, MA: Harvard University Press. Cassiman, B., and R. Veugelers. 2002. "R\&D cooperation and spillovers: some empirical evidence from Belgium." American Economic Review, 92(4): 1169-1184.

Cattani, G., and J.H. Kim. 2017. "Knowledge diversity, organizational learning and performance." Academy of Management, 2017(1): 15774.

Chen, J., Y. Chen, and W. Vanhaverbeke. 2011. "The influence of scope, depth and orientation of externaltechnology sources on the innovative performance of Chinese firms." Technovation, 31(8): 362-373.

Chesbrough, H. 2003. Open Innovation: Harvard University Press, Cambridge, MA.

Chesbrough, H., and A.K. Crowther. 2006. "Beyond high tech: early adopters of open innovation in other industries." R\&D Management, 36(3): 229-236.

Chiang, Y.H., and K.P.Hung. 2010. "Exploring search and perceived innovation performance from the perspective of inter-organizational knowledge flows.” R\&D Management, 40(3): 292-299.

Cohen, W. M., and D.A. Levinthal. 1989. "Innovation and learning: The two faces of R\&D." The Economic Journal, 99(397): 569-596.

Cohen, W. M., and D.A. Levinthal. 1990. "Absorptive capacity: A new perspective on learning and innovation." Administrative Science Quarterly, 35(1): 128-152.

Cohen, W. M., and D.A. Levinthal. 1994. "Fortune favours the prepared firm." Management Science, 40(2): 227251.

Cohen, W. M., R.R. Nelson, and J.P. Walsh. 2002. "Links and impacts: The influence of public research on industrial R\&D." Management Science, 48(1): 1-23.

Criscuolo, P., K. Laursen, T. Reichstein, and A. Salter. 2018. "Winning combinations: search strategies and innovativeness in the UK." Industry and Innovation, 25(2): 115-143.

Dahlander, L., and D.M. Gann. 2010. "How open is innovation?" Research Policy, 39(6): 699-709.

Day, G. S., and R. Wensle. 1988. "Assessing advantage: A framework for diagnosing competitive superiority." Journal of Marketing, 52(2): 1-20.

Dickson, P. R. 1992. "Toward a general theory of competitive rationality." Journal of Marketing, 56(1): 69-83.

Dominici, G., and G. Levanti. 2011. "The complex system theory for the analysis of inter-firm network: A literature overview and theoretic framework." International Business Research, 4(2): 31-37.

Dong, J.Q., and J. Netten. 2017. "Information Technology and external search in the open innovation age: New findings from Germany." Journal of Technological Forecasting \& Social Change, 120 (2017): 223-231.

Dosi, G. (1995b), "The contribution of economic theory to the understanding of a knowledge-based economy", IIASA, Laxenburg, Austria, Working Paper, WP 95-56. 
Ebersberger, B., and S.J. Herstad. 2013. "The relationship between international innovation collaboration, instrumentalR\&D and SMEs ' innovation performance: A quantile regression approach." Applied Econometric Letters, 20(7): 626-630.

Enkel, E., O. Gassmann, and H. Chesbrough. 2009. "Open R\&D and open innovation: Exploring the phenomenon.” R\&D Management, 39(4): 311-316.

Escribano, A., A. Fosfuri, and J.A. Tribo. 2009. "Managing external knowledge flows: The moderating role of absorptive capacity." Research Policy, 38(1): 96-105.

Felin, T. and T.R. Zenger. 2016. "Strategy, problems, and theory for the firm." Organization Science, $27(1): 222-231$. Felin, T., and T.R. Zenger. 2017. "The theory-based view: Economic actors as theorists." Strategy Science, 2(4): 258271.

Felin, T., and T.R. Zenger. 2020. “Open innovation: A theory-based view.' Strategic Management Review, 1(2): 223232.

Ferreras-Mendez, J.L., S. Newell, A. Fernandez-Mesa, and J. Alegre. 2015. "Depth and breadth of external search and performance: The mediating role of absorptive capacity." Industrial Marketing Management, 47(2015): 86-97.

Fey, C., and J. Birkinshaw. 2005. 'External sources of knowledge, governance mode and R\&D performance.' Journal of Management, 31(4): 597-621.

Flor, M.L., S.Y. Cooper, and M.J. Oltra-Mestre. 2018. "External knowledge search, absorptive capacity and radical innovation in high-technology firms." European Management Journal, 36(2): 183-194.

Frey, K., C. Luethje, and S. Haag. 2011. "Whom should firms attract to open innovation platforms? The role of knowledge diversity and motivation." Journal of Long-Range Planning, 44(2011): 397-420.

Galende, J., and J.M. De la Fuente. 2003. "Internal factors determining a firm"s innovative behavior." Research Policy, 32(5): 715-736.

Garcia, L.M., A.A. Oliveira, R.A. Grupen, D.S. Wheeler, and A.H. Fagg. 2000. "Tracing patterns and attention: humanoid robot cognition." IEEE Intelligent Systems, 15(4): 70-77.

Gassmann, O. and E. Enkel. 2004. "Towards a theory of open innovation: Three core process Archetypes." University of St. Gallen.

Gassmann, O., E. Enkel, and H. Chesbrough.2010. “The future of open innovation.” R\&D Management, 40(3): 213221.

Gkypali, A., D. Filiou, and K. Tsekouras. 2017. "R\&D collaborations: Is diversity enhancing innovation performance?" Technological Forecasting and Social Change, 118(2017): 143-152.

Gómez, J., I. Salazar, and P. Vargas. 2016. "Sources of information as determinants of product and process innovation." Journals.PloS One, 11(4): e0152743.

Granovetter, M. 1973. "The strength of weak ties." The American Journal of Sociology, 78(1973): 1360-1380.

Grant, R. M. 1996. "Toward a knowledge-based theory of the firm.” Strategic Management Journal, 17 (1996): 109122.

Hansen, M. T. 1999. "The search-transfer problem: The role of weak ties in sharing knowledge across organization subunits." Administrative Science Quarterly, 44(1): 82-111.

Hargadon, A., and R.I. Sutton. 1997. "Technology brokering and innovation in a product development firm." Administrative Science Quarterly, 42(4): 716-749.

Herfindahl, O.C. 1950. "Concentration in the steel industry." PhD diss., Columbia University, OCLC 5732189.

Hirschman, A.O. 1946. "National power and the structure of foreign trade." American Political Science Review, 40(1): 146-147.

Hoffman, K., M. Parejo, J. Besana, and L. Perren. 1998. "Small firms, R\&D, technology and innovation in the UK: a literature review." Technovation, 18(1): 39-55.

Hwang, J. and Y. Lee. 2010. "External knowledge search, innovative performance and productivity in the Korean ICTsector." Telecommunications Policy, 34(10): 562-571.

Kang, K.H., and J. Kang. 2009. "How do firms source external knowledge for innovation: Analyzing effects of different knowledge sourcing methods." International Journal of Innovative Management, 13(1): 1-17.

Katila, R. 2002. "New product search over time: Past ideas in their prime?" The Academy of Management Journal, 45(5): 995-1010.

Katila, R., and G. Ahuja. 2002. "Something old, something new: A longitudinal study of search behavior and new product introduction." The Academy of Management Journal, 45(6): 1183-1194.

Kline, S., and N.Rosenberg. 1986. "An Overview of innovation. In R. Landau, \& N. Rosenberg (Eds.), The Positive Sum Strategy: Harnessing Technology for Economic Growth" Washington, DC: National Academy of Sciences. 275306. 
Laursen, K., and A. Salter. 2006. "Open for innovation: the role of openness in explaining innovation performanceamong U.K. manufacturing firms." Strategic Management journal, 43(5): 867-878.

Laursen, K., and A. Salter, 2014. "The paradox of openness: Appropriability, external search and collaboration." Research Policy, 33(8): 1201-1215.

Lee, A. H., W. M. Wang, and T.Y. Lin. 2010. "An evaluation framework for technology transfer of new equipment in the high technology industry." Technological Forecasting and Social Change, 77(1): 135-150.

Leiponen, A., and C.E. Helfat. 2010. "Innovation objectives, knowledge sources, and the benefits of breadth." Strategic Management, 31(2): 224-236.

Leiponen, A., and C.E. Helfat. 2011. "Location, decentralization, and knowledge sources for innovation." Organization Science, 22(3): 641-658.

Lin, B. W., and C. H.Wu. 2010. "How does knowledge depth moderate the performance of internal and external knowledge sourcing strategies?" Technovation, 30(11-12): 582-589.

Lind, J.T., and H. Mehlum. 2010. "With or without U? The appropriate test for a U-shaped relationship." Oxford Bulletinof Economics and Statistics, 72(1): 109-118.

Love, J.H., and M.A. Mansury. 2007. "External linkages, R\&D and innovation performance in US business services." Industry and Innovation, 14(5): 477-496.

Lukas, B. A., and O.C. Ferrell. 2000. "The effect of market orientation on product innovation." Journal of the Academy of Marketing Science, 28(2): 239-247.

Lundvall, B. A. 2007. "National innovation systems - Analytical concept and development tool." Industry and Innovation, 14(1): 95-119.

Mannheim Innovation Panel, https:/www.zew.de/en/publications/zew-expertises-researchreports/research-reports/innovations/mannheim-innovation-panel-the-annual-german-innovation-survey.

March, J.G. 1991. "Exploration and exploitation in organizational learning." Organization Science, 2(1): 1-147.

Maskell, P., H. Bathelt, and A. Malmberg. 2006. "Building global knowledge pipelines: The role of temporary clusters." European planning studies, 14(8): 997-1013.

Medase, S.K., and S. Abdul-Basit. 2020. "External Knowledge modes and firm-level innovation performance: Empirical evidence from sub-Saharan Africa." Journal of Innovation \& Knowledge, 5(2020): 81-95.

Miotti, L., and F. Sachwald. 2003. "Co-operative R\&D: Why and with whom? An integrated framework of analysis." Research Policy, 32(8): 1481-1499.

Ocasio, W., 1997. “Towards an attention-based view of the firm.” Strategic Management Journal, 18(SI): $187-206$.

Ocasio, W., 2011. "Attention to attention.” Organization Science, 22(5): 1286-1296.

OECD. 2005. The measurement of scientific and technological activities. In Oslo Manual. Guidelines forcollecting and interpreting innovation data (3rd ed.). Paris: OECD EUROSTAT.

Poot, T., D. Faems, and W. Vanhaverbeke. 2009. "Toward a dynamic perspective on open innovation: a longitudinal assessment of the adoption of internal and external innovation strategies in the Netherlands." International Journal of Innovation Management, 13(2): 177-200.

Radicic, D. 2020. "Breadth of external knowledge search in service sector." Business Process Management Journal, 27(1): 230-252.

Romero, I., and J.A. Martinez-Roman. 2012. "Self-employment and innovation. Exploring the determinants of innovative behavior in small businesses." Research Policy, 41(1): 178-189.

Romijn, H., and M. Albaladejo. 2002. "Determinants of innovation capability in small electronics and software firms in southeast England." Research Policy, 31(7): 1053-1067.

Rosenkopf, L., and A. Nerkar. 2001. "Beyond local search: Boundary-spanning, exploration, and impact in the optical disk industry." Strategic Management Journal, 22(4): 287-306.

Segarra-Cipres, M., and J.C. Bou-LIusar. 2018. "External knowledge search for innovation: The role of firms innovation strategy and industry context." Journal of Knowledge Management, 22(2): 280-298.

Simon, H.A., 1947. Administrative Behavior. Macmillan, Chicago, IL.

Simpson, E.1947. "Measurement of diversity". Nature. 163,688(1949).

Teece, D.J. 1986. "Profiting from technological innovation: Implications for integration, collaboration, licensing and public policy." Research Policy,15(6): 285-305.

Teece, D. J. 2000. "Strategies for managing knowledge assets: The role of firm structure and industrial context." Long Range Planning, 33(1): 35-54.

Terjesen, S., and P.C. Patel. 2015. "In search of process innovations: the role of search depth, search breadth and the industry environment." Journal of Management, 43(5): 1421-1446.

Tether, B. S., and A. Tajar. 2008. "Beyond industry-university links: Sourcing knowledge for innovation from consultants, private research organizations and the public science-based." Research Policy, 37(6-7): 1079-1095. 
Tortoriello, M., B. McEvily, and D. Krackhardt. 2014. "Being a catalyst of innovation: The role of knowledge diversity and network closure." Organization Science, 26(2): 311-631.

Trantopoulos, K., G. von-Krough, M.W. Wallin, and M. Woerter. 2017. "External knowledge and information technology: Implications for process innovation performance." MIS Quarterly, 41(1): 287-300.

Varga, A., D. Pontikakis, and G. Chorafakis. 2014. "Metropolitan Edison and cosmopolitan Pasteur? Agglomeration and interregional research network effects on European R\&D productivity." Journal of Economic Geography, 14(2): 229-263.

von Hippel E., and G.von Krogh. 2016. "Crossroads-Identifying viable need-solution pairs: Problem solving without problem formulation." Organization Science., 27(1): 207-221.

Zahra,S.A., and G.George. 2002. "Absorptive capacity: A review, reconceptualization and extension." Academy of Management Review, 27(2): 185-202.

Zhou, K.Z., and C.B. Li. 2012. "How knowledge affects radical innovation: knowledge base, market knowledge acquisition, and internal knowledge sharing." Strategic Management Journal, 33(9): 1090-1102. 


\section{Table 1}

Summary of measures

\begin{tabular}{|c|c|c|}
\hline Variable & Description & Scale \\
\hline Vertical cluster & $\begin{array}{l}\text { Summation of percentage of firms having used suppliers, private clients, } \\
\text { public clients divided by summation of percentage of firms not having used } \\
\text { suppliers, private clients or public clients }\end{array}$ & $0-4$ \\
\hline Horizontal cluster & $\begin{array}{l}\text { percentage of firms having used competitors divided by percentage of firms } \\
\text { not having used competitors }\end{array}$ & $0-5$ \\
\hline Societal cluster & $\begin{array}{l}\text { summation of percentage of firms having used consultants, government, } \\
\text { private research institutes and professional associations divided by } \\
\text { summation of percentage of firms nothing used consultants, government, } \\
\text { private research institutes and professional associations }\end{array}$ & $0-7$ \\
\hline Specialized cluster & $\begin{array}{l}\text { Summation of percentage of firms having used universities, conferences and } \\
\text { scientific journals divided by summation of percentage of firms not having } \\
\text { used universities, conferences and scientific journals. }\end{array}$ & $0-6$ \\
\hline Diversity & Inverse of the summation of fraction of clusters divided by total sources & $0-2$ \\
\hline & squared $\overline{\sum_{i=1}^{4}\left(\frac{U_{i}}{N}\right)^{2}}$ & \\
\hline Breadth & $\begin{array}{l}\text { Summation of percentages of usage of all eleven sources in each industry, } \\
\sum_{i=1}^{11} u_{i}\end{array}$ & $0-3$ \\
\hline $\mathrm{R} \& \mathrm{D}$ & In house $R \& D$ expenditure & $27-110$ in thousands \\
\hline Industry dummy & Whether industries belong to manufacturing, service or retail & $\begin{aligned} 2= & \text { retail, } 1=\text { manufacturing } \\
0 & =\text { service }\end{aligned}$ \\
\hline Market size & $\begin{array}{l}\text { weighted average of percentage of firms in the industry who sell in local, } \\
\text { national, European and international markets with } 1,4,8,16 \text { as weights } \\
\text { respectively }\end{array}$ & $0-30$ \\
\hline
\end{tabular}

Table 2

Descriptive statistics and correlations-part 1

\begin{tabular}{|c|c|c|c|c|c|c|c|c|}
\hline & Mean & SD & (1) & (2) & (3) & (4) & (5) & (6) \\
\hline Vertical & 0.74 & 0.46 & & & & & & \\
\hline Horizontal & 1.68 & 0.85 & 0.81 & & & & & \\
\hline Societal & 1.65 & 1.17 & 0.80 & 0.74 & & & & \\
\hline Specialized & 2.22 & 1.07 & 0.65 & 0.56 & 0.72 & & & \\
\hline R\&D & 5.83 & 2.28 & -0.18 & -0.1 & -0.11 & -0.16 & & \\
\hline $\begin{array}{l}\text { Industry } \\
\text { dummy }\end{array}$ & 0.5 & 0.6 & 0.16 & -0.7 & -0.23 & -0.72 & 0.60 & \\
\hline Market size & 11.81 & 6.36 & -0.01 & 0.09 & 0.14 & -0.02 & -0.1 & -0.39 \\
\hline
\end{tabular}


Table 3

Descriptive statistics and correlations-Part 2

\begin{tabular}{|c|c|c|c|c|c|}
\hline & Mean & SD & (1) & (2) & (3) \\
\hline Diversity & 0.13 & 0.6 & & & \\
\hline $\mathrm{RD}$ & 5.83 & 2.28 & 0.11 & & \\
\hline Industry dummy & 0.5 & 0.6 & -0.09 & -0.02 & \\
\hline Market Size & 11.81 & 6.36 & 0.13 & 0.38 & 0.45 \\
\hline
\end{tabular}

\section{Table 4}

Descriptive statistics and correlations-part 3

\begin{tabular}{ccccc}
\hline & Mean & SD & $(1)$ & (2) \\
\hline Breadth & 1.09 & 0.35 & & \\
RD & 5.83 & 2.28 & 0.4 & \\
Industry dummy & 0.5 & 0.6 & -0.05 & -0.05 \\
Market Size & 11.81 & 6.36 & 0.26 & 0.46 \\
\hline
\end{tabular}

\section{Table 5}

Random effect OLS and GLS for source clusters and innovation

\begin{tabular}{|c|c|c|}
\hline & OLS & GLS \\
\hline Vertical cluster & $\begin{array}{c}9.50 * * * \\
(3.062)\end{array}$ & $\begin{array}{c}10.42 * * * \\
(2.967)\end{array}$ \\
\hline Horizontal cluster & $\begin{array}{c}7.31 * * * \\
(2.38)\end{array}$ & $\begin{array}{c}7.01 * * * \\
(2.329)\end{array}$ \\
\hline Societal cluster & $\begin{array}{c}4.19^{* * *} \\
(1.352)\end{array}$ & $\begin{array}{c}3.88 * * * \\
(1.367)\end{array}$ \\
\hline Special cluster & $\begin{array}{l}3.47 * * \\
(1.815)\end{array}$ & $\begin{array}{l}3.15 * * * \\
(1.741)\end{array}$ \\
\hline $\mathrm{R} \& \mathrm{D}$ & $\begin{array}{c}3.19 * * * \\
(0.69)\end{array}$ & $\begin{array}{c}2.79 * * * \\
(0.729)\end{array}$ \\
\hline Industry dummy & $\begin{array}{c}-7.16 * * * \\
(2.651)\end{array}$ & $\begin{array}{c}-6.13 \\
(2.806)\end{array}$ \\
\hline Market size & $\begin{array}{l}1.19^{* * *} \\
(0.299)\end{array}$ & $\begin{array}{l}1.22 * * * \\
(0.282)\end{array}$ \\
\hline Intercept & $\begin{array}{c}-6.72 * \\
(10.056)\end{array}$ & $\begin{array}{c}-4.49 \\
(10.154)\end{array}$ \\
\hline$R^{2}$ & 0.56 & 0.57 \\
\hline Adjusted $R^{2}$ & 0.52 & 0.53 \\
\hline
\end{tabular}

Note: ${ }^{*} \mathrm{p}<0.1 ; * \mathrm{p}<0.05 ;{ }^{* *} \mathrm{p}<0.01$ - standard errors are in parenthesis. Dependent variable is innovation performance 


\section{Table 6}

Random effects OLS and GLS for breadth and innovation

\begin{tabular}{|c|c|c|}
\hline & OLS & GLS \\
\hline Breadth & $\begin{array}{c}0.15 * * * \\
(0.04)\end{array}$ & $\begin{array}{c}0.15 * * * \\
(0.05)\end{array}$ \\
\hline $\mathrm{R} \& \mathrm{D}$ & $\begin{array}{c}0.03 * * * \\
(0.007)\end{array}$ & $\begin{array}{c}0.03 * * * \\
(0.007)\end{array}$ \\
\hline Industry Dummy & $\begin{array}{c}-0.05^{* *} \\
(0.03)\end{array}$ & $\begin{array}{c}-0.05 * * * \\
(0.02)\end{array}$ \\
\hline Market size & $\begin{array}{c}0.007 * * * \\
(0.002)\end{array}$ & $\begin{array}{c}0.008 * * * \\
(0.003)\end{array}$ \\
\hline Intercept & $\begin{array}{c}0.16 * * * \\
(0.05)\end{array}$ & $\begin{array}{c}0.17 * * * \\
(0.04)\end{array}$ \\
\hline$R^{2}$ & 0.546 & 0.553 \\
\hline Adjusted $\boldsymbol{R}^{2}$ & 0.524 & 0.531 \\
\hline
\end{tabular}

Note: ${ }^{*} \mathrm{p}<0.1 ;{ }^{* *} \mathrm{p}<0.05 ;{ }^{* * *} \mathrm{p}<0.01$ - standard errors are in parenthesis. Dependent variable is innovation performance

Table 7

Random effects OLS, GLS and quantile regression for diversity and innovation

\begin{tabular}{|c|c|c|c|c|}
\hline & OLS & GLS & quantile kernel & quantile bootstrap \\
\hline \multirow[t]{2}{*}{ Diversity } & $0.25 * *$ & $0.23 * *$ & $0.22 *$ & $0.23 * *$ \\
\hline & $(0.1)$ & $(0.097)$ & $(0.128)$ & $(0.095)$ \\
\hline \multirow[t]{2}{*}{ Diversity squared } & $-0.04 * *$ & $-0.03 * *$ & -0.03 & $-0.03 * *$ \\
\hline & $(0.018)$ & $(0.018)$ & $(0.024)$ & $(0.017)$ \\
\hline \multirow[t]{2}{*}{$\mathrm{R} \& \mathrm{D}$} & $0.03 * * *$ & $0.03 * * *$ & $0.03 * * *$ & $0.03 * * *$ \\
\hline & $(0.007)$ & $(0.007)$ & $(0.008)$ & $(0.006)$ \\
\hline \multirow{2}{*}{ Industry dummy } & $-0.06 * *$ & $-0.05 * *$ & $-0.09 * * *$ & $-0.09 * * *$ \\
\hline & $(0.027)$ & $(0.028)$ & $(0.032)$ & $(0.026)$ \\
\hline \multirow[t]{2}{*}{ Market size } & $0.01 * * *$ & $0.01 * * *$ & $0.009^{* * *}$ & $0.009 * * *$ \\
\hline & $(0.002)$ & $(0.003)$ & $(0.003)$ & $(0.002)$ \\
\hline \multirow[t]{2}{*}{ Intercept } & $0.28 * * *$ & $0.29 * * *$ & $0.349 * * *$ & $0.349 * * *$ \\
\hline & $(0.036)$ & $(0.042)$ & $(0.046)$ & $(0.033)$ \\
\hline$R^{2}$ & 0.52 & 0.51 & 0.61 & 0.63 \\
\hline Adjusted $R^{2}$ & 0.49 & 0.48 & 0.60 & 0.61 \\
\hline
\end{tabular}

Note: ${ }^{*} \mathrm{p}<0.1 ;{ }^{* *} \mathrm{p}<0.05 ;{ }^{* *} \mathrm{p}<0.01$ - standard errors are in parenthesis. Dependent variable is innovation performance 


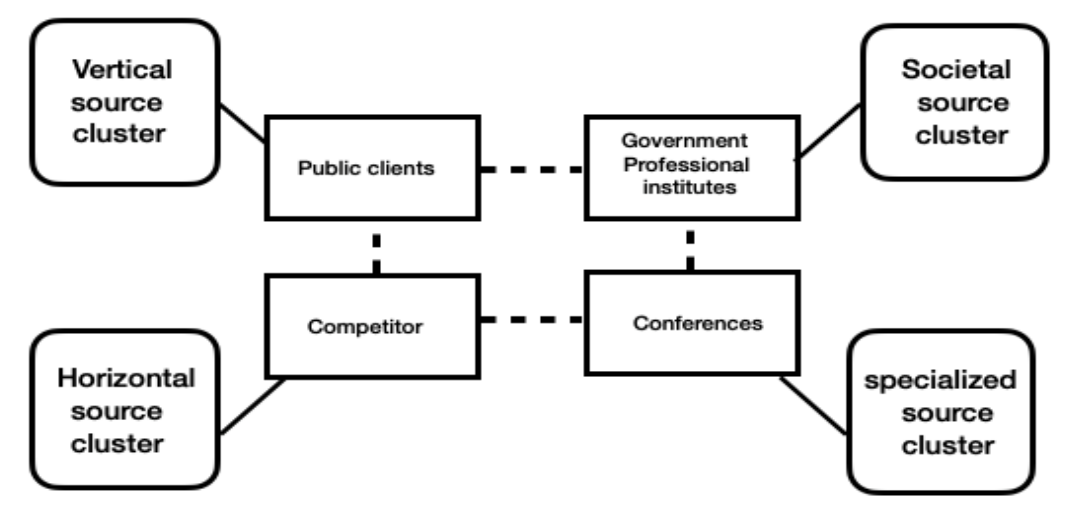

Knowledge search breadth in both cases $=5$

$\underline{1}$

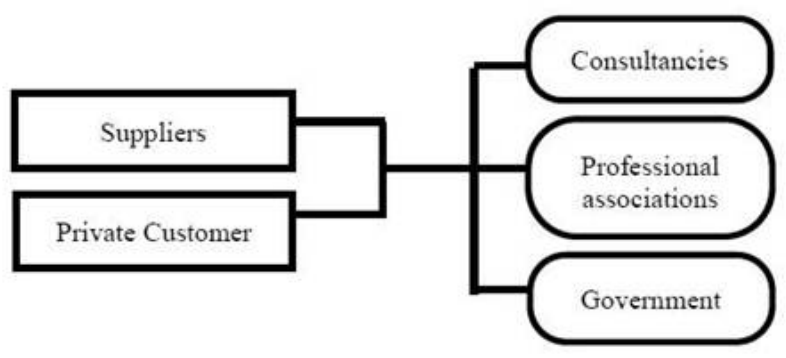

$n_{1}=2$ (number of sources in vertical class)

$n_{2}=3$ (number of sources in societal class)

$N=5$ (total number of sources or search breadth)

$P_{1}=\frac{n_{1}}{N}=\frac{2}{5} \quad P_{\overline{2}}=\frac{n_{2}}{N}=\frac{3}{5}$

Diversity $=\frac{1}{\sum p_{i}^{2}}=\frac{1}{\left(\frac{2}{5}\right)^{2}+\left(\frac{3}{5}\right)^{2}}=1.9$ $\underline{2}$

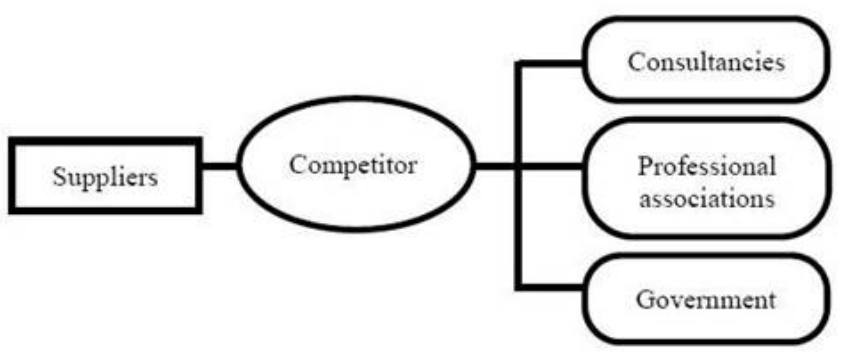

$n_{1}=1$ (number of sources in vertical class)

$n_{2}=1$ (number of sources in horizontal class)

$n_{3}=3$ (number of sources in societal class)

$N=5$ (total number of sources or search breadth)

$P_{1}=\frac{n_{1}}{N}=\frac{1}{5} \quad P_{\overline{2}} \frac{n_{2}}{N}=\frac{1}{5} \quad P_{3}=\frac{n_{3}}{N}=\frac{3}{5}$

Diversity $=\frac{1}{\sum p_{i}^{2}}=\frac{1}{\left(\frac{1}{5}\right)^{2}+\left(\frac{1}{5}\right)^{2}+\left(\frac{3}{5}\right)^{2}}=\mathbf{2 . 2 7}$ 


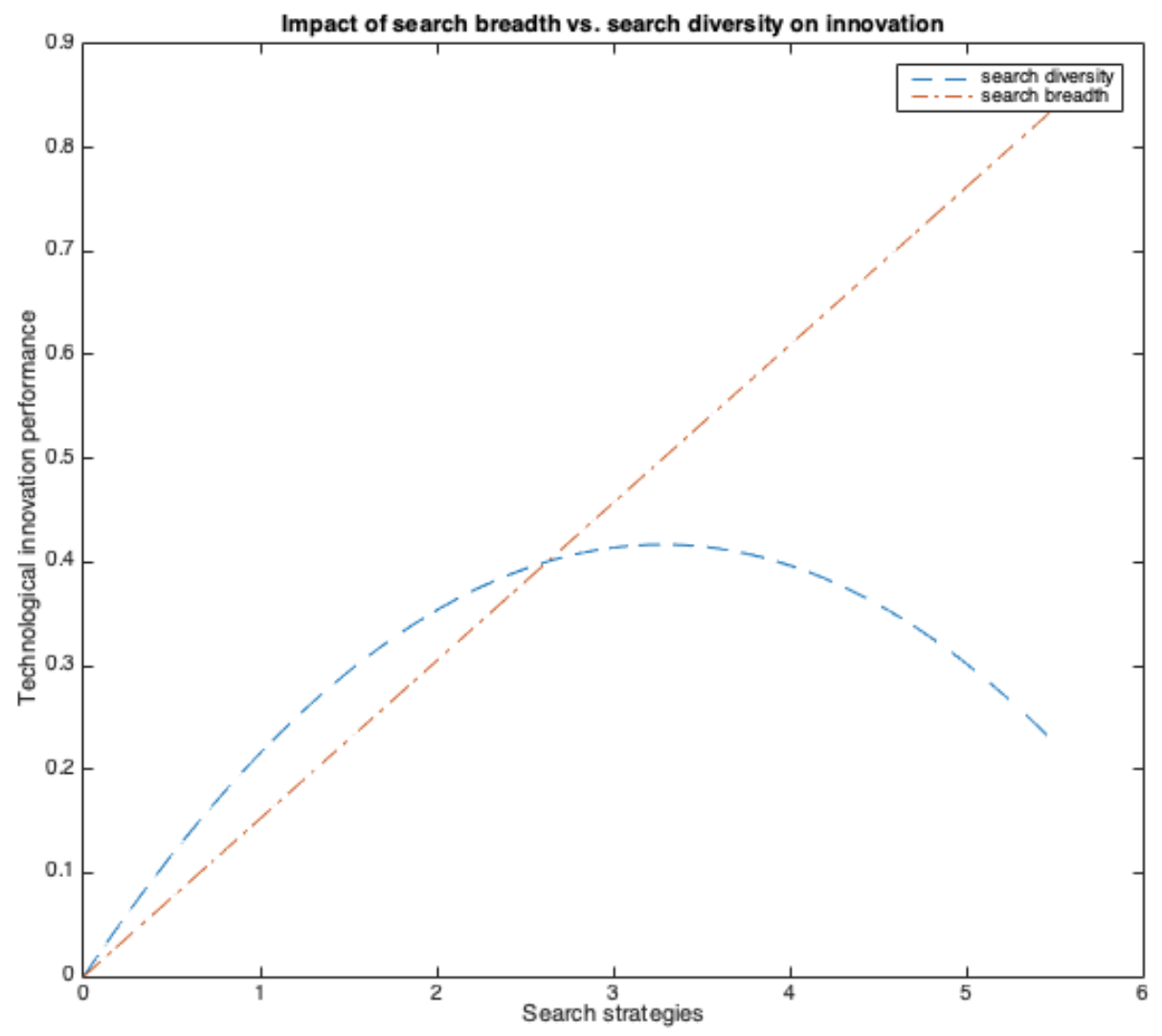

\section{Figures}

Figure 1. A Source network of five sources from four categories

Figurer 2 - Verification of knowledge diversity

Figure 3. Search breadth, search diversity and a hybrid search strategy 